\title{
Mediatyzacja jako wyzwanie dla politologa
}

\section{Mediatization - A Challenge for Political Scientists}

\begin{abstract}
Mediatization is a process that is interesting to a researcher and political scientist for at least two important reasons. On the one hand, it becomes the area of scientific researches, inspirations and reflections, as it encourages to observe the changing frameworks, within which the political entities function, as well as the instruments and means used by them to complete tasks and achieve goals. However, on the other hand, mediatization is also a process which has impact on scientific environments, including also the community of political scientists, which seems to be a particularly interesting collective entity. This environment not only observes and describes the reality of mediatization, but also actively participates in its creation by means of diverse activities of researchers in the media. The author makes an attempt to indicate what are the implications of this media activity of researchers and what dilemmas it raises.
\end{abstract}

Keywords: mediatization, discourse, public sphere, political science, mass media Słowa kluczowe: mediatyzacja, dyskurs, sfera publiczna, nauki o polityce, media

Nie trzeba być uważnym obserwatorem lub badaczem, żeby dostrzec zjawisko wzajemnego, dwukierunkowego oddziaływania mediów i polityki. To, co w naszym otoczeniu widzimy często „gołym okiem” albo czujemy intuicyjnie, ekspert zajmujący się problematyką komunikacji społecznej nazwie „mediatyzacją”.

Gdy używa tego pojęcia może mieć na myśli co najmniej kilka procesów. Może bowiem myśleć na przykład o tym, że to media umożliwiają aktorom politycznym dostęp do sfery publicznej. Decydując więc kto znajduje w niej swoje miejsce, a komu drzwi do niej zostaną zamknięte, środki społecznego przekazu definiują możliwości działania podmiotów politycznych. Inaczej mówiąc - mają wpływ na siłę ich oddziaływania. Pod pojęciem „mediatyzacja” kryje się również zjawisko polegające na tym, że informacje w przestrzeni społecznej są gromadzone i selekcjonowane wedle reguł medialnych. To właśnie te informacje, po dotarciu do odbiorców, stają się często jedyną przesłanką podejmowania obywatelskich działań. W tym przypadku więc także podkreślona zostaje siła środków masowej komuni- 
kacji. Podobnie, gdy mamy na myśli jeszcze inny proces, który ukrywać się może pod pojęciem „mediatyzacja”. Chodzi o wpływ mediów na sytuację polityczną. Przez tworzenie pseudowydarzeń i fikcyjnej rzeczywistości, oddziałują na bieżące wydarzenia, mogą zmieniać ich bieg, nadawać znaczenie, a wręcz kreować nowe działania ${ }^{1}$.

Niezależnie od tego, które rozumienie pojęcia mediatyzacja będziemy analizowali, dostrzec musimy szczególnie ważną rolę mediów w przebiegu procesów społecznych. Za sprawą środków masowego przekazu polityka stopniowo przestawała być sferą rywalizacji wartości i interesów, żeby stać się podobna do telenoweli czy pełnym emocji talk show. W centrum uwagi znalazły się więc konflikty i spory, bo to one nadają rys dramaturgiczny prezentowanej narracji. Uwaga została w niej skoncentrowana na wąskich problemach, które dają się obrazowo i widowiskowo wykorzystać w prowadzeniu bieżącej walki politycznej. Co ważne - nie muszą to być oczywiście kwestie najistotniejsze dla funkcjonowania państwa, społeczeństwa czy określonych grup.

Nie angażując się więc w spory definicyjne dotyczące „mediatyzacji”, przyjmijmy, że chodzi nam tutaj o - wciąż postępujący i pogłębiający się - proces polegający na udziale mediów w wyznaczaniu ram debaty publicznej, w określaniu pożądanych zachowań społecznych i postaw, a także w kreowaniu rzeczywistości. $\mathrm{Z}$ faktu, że media zajmują pozycję dominującą w procesach społecznych i stanowią szczególnie istotne ogniwo komunikacji, wypływają określone konsekwencje. Dotyczą one sfery jakości debaty publicznej, sposobu uprawiania polityki, a także sposobu komunikacji - pomiędzy podmiotami polityki, pomiędzy tymi podmiotami a obywatelami oraz pomiędzy samymi obywatelami.

Jako zjawisko dające się obserwować w przestrzeni społecznej mediatyzacja stanowi proces interesujący badacza-politologa z co najmniej dwóch istotnych powodów. $Z$ jednej strony bowiem staje się obszarem naukowych poszukiwań, inspiracji i refleksji. Zachęca do obserwacji zmieniających się ram funkcjonowania podmiotów politycznych, wykorzystywanych przez nie narzędzi i środków służących realizacji zadań i osiągania celów. $Z$ drugiej natomiast jest także procesem wpływającym na środowiska naukowe, w tym na środowisko politologów, które wydaje się być szczególnie interesującym podmiotem zbiorowym. Nie tylko obserwuje i opisuje mediatyzacyjną rzeczywistość, ale też aktywnie uczestniczy w jej tworzeniu, chociażby przez aktywność badaczy w mediach. A te „są z pewnością najważniejszym miejscem, w którym dochodzi do kontaktu między nauką (na-

1 Por. B. Dobek-Ostrowska, Komunikowanie polityczne i publiczne, Warszawa 2007, s. 158-159. 
ukowcami) a publicznością nieprofesjonalną"2. Musi to rodzić określone implikacje, które warto w tym miejscu naświetlić.

Mając rzecz jasna świadomość, że choć w sposób szczególny będziemy przyglądać się reprezentantom nauk o polityce, podobne problemy mogą dotyczyć również innych środowisk akademickich i grup badaczy. Ponadto poczynić trzeba w tym miejscu jeszcze jedno ważne zastrzeżenie. Otóż, dylematy związane z procesem mediatyzacji, zrodzone w jego ramach nie są od początku do końca nowe. Należałoby raczej powiedzieć, że są to nierzadko stare, dobrze znane już wcześniej dylematy, tyle że wpisane w nową rzeczywistość. To znaczy, że występują w nowym kontekście. Warto więc pamiętać, że przynajmniej część z podnoszonych tutaj problemów była brana pod uwagę już wcześniej.

Jednym z zadań politologów jest pomoc w objaśnianiu otaczającej nas, wielowymiarowej i wielopłaszczyznowej rzeczywistości. Stają się więc oni jednym z ogniw procesu opiniotwórczego - obok przedstawicieli elit politycznych, społecznych i gospodarczych, innych tak zwanych „przywódców opinii” oraz oczywiście mediów. W procesie tym politolodzy stają się swoistymi tłumaczami. Oczekuje się od nich, że skomplikowane kwestie, mechanizmy świata polityki przełożą na język zrozumiały dla przeciętnego odbiorcy. Błędem środowiska naukowego byłoby więc zamykanie się w umownej „szklanej wieży” i badanie jedynie problemów niezrozumiałych dla szerokich mas odbiorców ${ }^{3}$. Mając świadomość tej szczególnej roli, czy - jak można by powiedzieć - misji politologów, warto podjąć refleksję nad zagadnieniem mediatyzacji przez nich uprawianej. Sama bowiem mediatyzacja może być widziana jako zagrożenie (standardów - chociażby), ale też może być postrzegana jako zadanie i wyzwanie.

\section{Debaty nad debatą}

Refleksja nad mediatyzacją prowadzi nas do podzielanej przez wielu badaczy i obserwatorów myśli o zepsuciu debaty publicznej właśnie przez środki masowego przekazu i sposób ich działania. Powiedzą oni, że przeobrażenia w zakresie funkcjonowania mediów prowadzą do ograniczenia czy wręcz całkowitego zredukowania możliwości prowadzenia rzeczywistej - rozumianej jako przeciwieństwo pozornej - debaty publicznej. Mamy oto do czynienia ze swoistą dychotomią.

2 A. Paczkowski, Nauka w mediach. Nieco luźnych uwag, [w:] Medializacja Nauki, red. B. Gruszka, Warszawa 2004, s. 10.

3 Por. H. Samsonowicz, Stowo wstępne, [w:] Medializacja..., s. 7. 
Z jednej bowiem strony powszechność środków masowej komunikacji zapewniła szerokiej części społeczeństwa dostęp do publicznego dyskursu. Tyle, że - i to jest ta druga, ciemniejsza strona rzeczywistości - dyskurs ten został jednocześnie poddany daleko idącemu zubożeniu, albowiem miejsce racjonalnej argumentacji zajął przekaz emocjonalny, symboliczny, metaforyczny. Chętnie sięga się w nim po etykiety - mocne słowa czy wyrażenia, za pomocą których oskarża się przeciwnika lub dyskutanta. Powinno to niepokoić, ponieważ - jak zauważyła Katarzyna Kłosińska - „zbytnia wyrazistość słowa przysłania nam rzeczywistość”’ szej perspektywie - zniechęca przeciętnego obywatela do uczestnictwa $\mathrm{w}$ sferze publicznej czy politycznej.

Niektórzy powiedzą, że funkcjonujemy w dobie „retoryki audiowizualnej”. To, co z założenia miało przybliżać obywateli do polityki, sprawiło, iż rozdźwięk pomiędzy nimi się poszerzył. Osobiste doświadczenie w przestrzeni politycznej zostało w wielu przypadkach wyparte przez doświadczenie medialne. Inaczej mówiąc - wielu, zamiast brać czynny udział w politycznych aktach i rytuałach, zadowala się ich obserwowaniem, rezygnując przy tym z możliwości nawiązania dialogu ${ }^{5}$.

Jednym z tych, którzy już przed laty zwracali uwagę na te procesy, jest Jürgen Habermas, który odnotowywał w swoich pracach przeobrażenia sfery publicznej, rozumianej przez niego jako istniejące pomiędzy państwem a prywatnym obywatelem pole czy forum debaty publicznej. Przyglądając się ewolucji tej przestrzeni, niemiecki filozof i socjolog doszedł do wniosku, że szanse związane z wykształceniem się sfery publicznej nie zostały w pełni wykorzystane. Zauważył, że posługujący się manipulacją przemysł kulturowy stłumił debatę we współczesnych społeczeństwach, czyniąc ją swoistym spektaklem, w którym interes publiczny schodzi na dalszy plan ${ }^{6}$.

W ten nurt myślenia o konsekwencjach przeobrażeń mediów wpisują się również refleksje Neila Postmana, który obserwując przeobrażenia dyskursu społecznego w Ameryce, doszedł do wniosku, że w czasie panowania prasy drukarskiej dyskurs ten był „konsekwentny, poważny i racjonalny”, z czasem jednak, wraz

4 K. Kłosińska, W polityce stowa przystaniaja rzeczywistość, (w rozm. z A. Kublik), Gazeta Wyborcza, 25.10.2010, s. 8 .

5 Por. B. Dobek-Ostrowska, Porozumienie czy konflikt? Politycy, media i obywatele w komunikowaniu politycznym, Warszawa-Bielsko-Biała 2009, s. 86-87.

6 Zob. J. Habermas, The Structural Transformation of the Public Sphere, Cambridge 1989, passim.

7 N. Postman, Zabawić się na śmierć, Warszawa 2002, s. 36. 
z rozwojem przemysłu medialnego, stał się „jałowy i bezsensowny”. W swojej najbardziej znanej pracy, zatytułowanej Zabawić się na śmierć, amerykański filozof i medioznawca ubolewał, że współcześnie mamy do czynienia ze strywializowaniem publicznej informacji, przez co „wchodzimy w środowisko informacyjne, które można by trafnie nazwać prostacką gonitwą" 9 . Szukając rozwinięcia tej myśli, znajdujemy w lekturze pogląd, iż nadrzędną ideą - wręcz nadideologią - dyskursu telewizyjnego stała się rozrywka. Z góry przyjmuje się więc założenie, że wszystko na szklanym ekranie ma służyć rozbawieniu i przyjemności. Według Postmana w naturze telewizji „leży (...) ów przymus tłumienia zawartości myślowej po to, by sprostać jego wymaganiom i wizualnej atrakcyjności, czyli ustąpić przed wartościami show-businessu"10. Przedstawiając taki wniosek, amerykański badacz odnotowywał również, że zmiany te nie ograniczają się jedynie do środowiska medialnego, ale wychodzą daleko poza jego ramy. Stąd myśl, że telewizyjny sposób przedstawiania świata został zaakceptowany jako swoisty wzór prezentacji świata w ogóle. Można zatem powiedzieć, że „w salach sądowych, klasach szkolnych, na salach operacyjnych i konferencyjnych, w kościołach, a nawet w samolotach ludzie już ze sobą nie rozmawiają - oni się wzajemnie rozweselają. Nie wymieniają idei, wymieniają się obrazami. Argumentują nie za pomocą zdań, lecz dobrego wyglądu, sławnych znakomitości i reklam"11.

Trudno się dziś nie zgodzić, że telewizja wciąż wyznacza ramy dyskursu. Choć bywa i tak, że mamy do czynienia jedynie z samymi ramami, bo na dyskurs nie starcza ani miejsca, ani czasu. Można w tym miejscu przywołać chociażby gorzką myśl Marcina Króla poświęconą telewizyjnym komentarzom wygłaszanym przez przedstawicieli nauk politycznych czy społecznych: „Specjaliści są naturalnie lepsi lub gorsi, ale i tak nie mają kiedy tego wykazać, bo daje im się najwyżej trzy minuty czasu, i to często przerywanego bardzo długimi pytaniami dziennikarza. Wytwarza to sytuację, kiedy - po pierwsze - trzeba się okropnie spieszyć, żeby cokolwiek powiedzieć, i - po drugie - bardzo trudno powiedzieć cokolwiek bardziej subtelnego, a więc zostaje tylko banał"12.

Tę myśl polskiego filozofa i historyka idei - zawartą w felietonie pod wymownym tytułem Głupota $T V$ - możemy uzupełnić, sięgając chociażby do refleksji jednego z najbardziej znanych współczesnych francuskich socjologów. W podobnym duchu swoje obserwacje dotyczące telewizyjnych debat zaprezentował Pierre

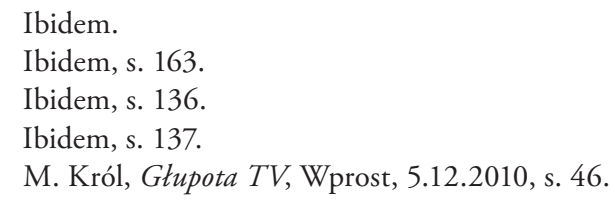


Bourdieu, uznając, że „telewizja uprzywilejowuje fast-thinkers proponujących kulturowy fast-food - już przetrawiony i przemyślany kulturowy pokarm”13. Według francuskiego socjologa z tego powodu telewizja nie jest najlepszym miejscem dla wyrażania myśli14 ${ }^{14}$. Ten wniosek można by dzisiaj odnieść również do innych mediów elektronicznych, które znalazły się w zasięgu przemian sposobów komunikowania i uległy procesom mediatyzacji i tabloidyzacji.

Niczym zaskakującym nie jest już dzisiaj to, że media - a szczególnie niektóre, także te, które przedstawiają się jako „informacyjne” - w prowadzonych debatach dążą wyraźnie do konfrontacji. Świadczy o tym nierzadko już sam sposób prowadzenia w nich rozmowy. Wywołane w ten sposób spięcie widziane jest jako szansa na zwiększenie liczby cytowań oraz wzrost zainteresowania audycją. Plik wideo z zapisem programu telewizyjnego oraz plik audio z fragmentem gorącej dyskusji radiowej zakończonej spektakularnym finałem staje się internetową atrakcją, mającą często dziesiątki tysięcy widzów i słuchaczy. Jest wielokrotnie odtwarzany przez użytkowników sieci, a dzięki kolejnym odsłonom staje się odrębnym bytem i sprzyja redundancji w obszarze tworzenia negatywnego wizerunku uczestników wyjątkowo emocjonalnej rozmowy - ale też uczestników dyskursu publicznego w ogóle. Tym samym może kłaść się cieniem na wizerunku środowiska, na przykład politologicznego.

Można powiedzieć, że polityka funkcjonuje w pewnych teatralnych ramach. I tak było zawsze. Problem pojawia się jednak wówczas, gdy media czynią z niej widowisko. A jak zauważa Maciej Mrozowski - o ile „teatr daje do myślenia, widowisko tylko do patrzenia"15. To patrzenie nie wymaga od widza pogłębionej wiedzy czy znajomości tematu, ponieważ w pojedynku na miny wygrywa ten, kto potrafi wywrzeć na publiczności lepsze wrażenie. Można to osiągnąć niekoniecznie sięgając po rzeczowe argumenty lub objaśniając szczytne idee. Z żalem należy przyznać, że w polskich realiach „dzisiaj jest to raczej walka na inwektywy, zagrywki i retoryczne popisy"16.

Niedoskonałości debaty publicznej dostrzegają nie tylko jej obserwatorzy, ale i sami jej uczestnicy. $\mathrm{Z}$ ich ust - oczywiście nie wszystkich - daje się raz po raz słyszeć krytykę sposobu dyskutowania w mediach. Pojawiają się więc opinie,

13 P. Bourdieu, O telewizji. Panowanie dziennikarstwa, Warszawa 2009, s. 57.

14 Paradoksalnie - swoją krytykę działania środowiska telewizyjnego Pierre Bourdieu prezentował w czasie wykładu wygłoszonego za pośrednictwem... telewizji.

15 M. Mrozowski, Myślenie w realu, celebryci w HD, [w:] S. Zawiśliński, Trudne tatwe czasy. Rozmowy z humanistami, Warszawa 2011, s. 189.

16 Ibidem. 
że „w debacie eksperckiej w Polsce zmieniono reguły gry i zwyciężyła zasada tabloidyzacji”" ${ }^{17}$ i że "potrzebna jest nam debata, a nie show”"

Przeobrażenia debaty dokonujące się pod wpływem mediów to tylko część rzeczywistości. Nie można bowiem zapominać, że nie tylko środki masowego przekazu ponoszą odpowiedzialność za styl i jakość dyskursu publicznego. Należy zwrócić tu także uwagę na samą politykę, której istotną cechą jest widowiskowość. Jak zauważa Lech Rubisz: „to nie media czynią z niej widowisko, ona sama jest jak widowisko"19, a skoro tak - ,jest grą nastawioną na zaspokajanie gustów powszechnych czy wręcz pospolitych" ${ }^{20}$. Nie bez znaczenia są też oczywiście przeobrażenia charakteru współczesnej polityki. Gdy zacierają się różnice między tradycyjnymi ideologiami i nie pojawiają się nowe projekty ideologiczne, głównym celem sporu politycznego staje się pokonanie przeciwnika politycznego, co prowadzi do spłaszczenia debaty politycznej ${ }^{21}$.

Poza tym, co nie mniej ważne, personalizacja sporów w polityce - także tych, dla których sceną stają się studia radiowe i telewizyjne - stanowi jedną z możliwych odpowiedzi na złożoność omawianych w debacie publicznej zagadnień. Formułując tę tezę, Hans Mathias Kepplinger zauważa, że większość kwestii politycznych cechuje tak duży poziom zawiłości, iż tylko specjaliści są w stanie je rozwikłać. Gdy więc uwaga zostaje skupiona nie na spornych kwestiach, ale na uczestnikach publicznego sporu - odbiorcom łatwiej jest opowiedzieć się po jednej ze stron konfliktu. Jak stwierdza niemiecki badacz mediów - „opinia na temat osoby jest rozsądną alternatywą dla oceny stanu rzeczy, którą jest w stanie ocenić w jeszcze mniejszym stopniu" 22 .

\section{Odpowiedzialność naukowców}

Gdy zastanawiamy się nad jakością odnoszących się do polityki debat toczonych za pośrednictwem środków masowego przekazu, nie możemy zapominać, że pewną rolę do odegrania mają w tym zakresie także naukowcy - w tym i politolodzy -

${ }_{17}$ M. Boni, Tabloidyzacja zaatakowata ekspertów, Gazeta Wyborcza, 26.10.2010, s. 17.

18 Ibidem.

19 L. Rubisz, Polityka jako widowisko, [w:] Mediatyzacja kampanii politycznych, red. M. Kolczyński, M. Mazur, S. Michalczyk, Katowice 2009, s. 112.

20 Ibidem.

21 Ibidem, s. 113.

22 H.M. Kepplinger, Demontaż polityki w spoteczeństwie informacyjnym, Kraków 2007, s. 151. 
którzy włączając się do publicznego dyskursu, wchodzą w krąg osób współodpowiedzialnych za jego stan. A różnie z tym stanem bywa ${ }^{23}$.

Aby nie ograniczać się tylko do ogólnych sądów, zilustrujmy tę myśl przykładami wyraźnie ukazującymi deficyty w debacie publicznej z udziałem ludzi nauki. Jeden z takich przykładów odnajdujemy w rozmowie, do której doszło w marcu 2011 roku w studiu jednej ze stacji telewizyjnych. Spotkali się w nim dwaj profesorowie: fizyk - Łukasz Turski oraz specjalista do spraw energetyki jądrowej - Władysław Mielczarski. Po tragicznym trzęsieniu ziemi, do którego doszło w Japonii, dyskutowali na temat bezpieczeństwa wokół uszkodzonej elektrowni atomowej Fukushima. Wyraźna różnica zdań pomiędzy interlokutorami doprowadziła do spięcia i użycia argumentacji ad personam (która - nota bene - jest stosunkowo często wykorzystywana w polskim dyskursie publicznym). Mielczarski zarzucił Turskiemu brak obiektywizmu („broni pan własnej pracy”). Następnie Mielczarski apelował do redakcji: „niech państwo nie zapraszają ludzi, którzy publicznie zarzucają mi pewne rzeczy”. W odpowiedzi usłyszał od Łukasza Turskiego: „To pan mi zarzuca różne rzeczy! Poza tym mówi pan rzeczy, które są nietolerowane”. Chwilę później padła ostra riposta Władysława Mielczarskiego (sprawiającego wrażenie nieświadomego, że program wciąż oglądają widzowie): „Z prymitywami, którzy... Pan mi coś zarzuca, że ja coś mówię. Proszę pana, kto panu dał tytuł? Kto panu dał tytuł, wieśniakowi jednemu?” - zakończył rozmowę profesor, wychodząc ze studia ${ }^{24}$.

Żeby jednak dotknąć rzeczywistości bliższej środowisku naukowemu zajmującemu się na co dzień problematyką polityczną, odwołajmy się do innego przykładu. Kłótnią w telewizyjnym studiu (w tym samym zresztą programie) zakończyło się spotkanie dwójki znanych socjologów - Jadwigi Staniszkis i Ireneusza Krzemińskiego. W czerwcu 2010 roku profesorowie dyskutowali na temat oceny bieżących wydarzeń, nie kryjąc przy tym swoich preferencji politycznych. W czasie spotkania Ireneusz Krzemiński przedstawiał się jako „zwolennik tej Polski, którą reprezentuje Platforma Obywatelska”. Z kolei Jadwiga Staniszkis chwaliła osiągnięcia prezesa Prawa i Sprawiedliwości. W finale rozmowy socjolog ironicznie zwracał się do swojej koleżanki słowami: „Myślisz, że na pomocy społecznej buduje się przyszłość Polski? Moje gratulacje...”. W odpowiedzi usłyszał: „Z Tobą nie można dyskutować”. Mówiąc to, Jadwiga Staniszkis ostentacyjnie wyszła ze

23 O dylematach politologów w obszarze medialnym piszę w: M. Zaborski, Politolog-komentator. Dylematy etyczne, Athenaeum. Polskie Studia Politologiczne, 2010, nr 26, s. 63-76.

24 „Kto panu dat tytut, wieśniakowi jednemu?” Profesorowie kłócą się na wizji o energię jądrową, http://www.tvn24.pl/12690,1695677,0,1,kto-panu-dal-tytul--wiesniakowi-jednemu,wiadomosc. html, odczyt z 30.08.2011. 
studia, a Ireneusz Krzemiński skomentował ten fakt: „Tym razem nie ja wyszedłem. Jestem zadowolony" 25 .

$\mathrm{Na}$ marginesie warto odnotować jeszcze jeden aspekt omawianego tu zjawiska, albowiem spory wykraczające poza standardy dyskursu naukowego obejmują również tych przedstawicieli świata nauki, którzy aktywnie działają w polu politycznym jako członkowie lub wyraźnie zdeklarowani stronnicy ugrupowań politycznych. Biorąc udział w publicystycznych audycjach radiowych i telewizyjnych, pojawiają się w nich jako politycy, zabiegający o poparcie dla swoich formacji. Nie sposób jednak zapomnieć o ich tytułach i stopniach, niezależnie od reprezentowanej dyscypliny naukowej. Zasadne wydaje się więc oczekiwanie, by w debatach politycznych lub publicystycznych prezentowali stanowiska z zachowaniem norm, które wyznacza doświadczenie i aktywność w środowisku akademickim.

Gdy w jednym z programów telewizyjnych w kwietniu 2014 roku spotkali się Jan Hartman i Stefan Niesiołowski i reprezentowali dwa środowiska polityczne Twój Ruch i Platformę Obywatelską, byli przedstawiani nie tylko jako politycy tych formacji, ale także jako profesorowie (zostało to przypomniane kilkakrotnie w czasie audycji). Nie przeszkodziło im to jednak w tym, by w czasie dyskusji sięgnąć po argumentację ad personam i za jej pomocą atakować rozmówcę. Ilustracją niech będzie krótki fragment programu, w którym politycy odnosili się do kwestii konkordatu i relacji państwo-Kościół ${ }^{26}$ :

S. Niesiołowski: „Pan mógłby się lepiej do tego programu przygotować, bo nieuctwo, które pan prezentuje, jest irytujące. Skąd te pokłady nieuctwa?”. J. Hartman: „Z pewnością nie znam się na owadach, ale poza tym nie jest źle". [odwołanie do entomologii, w której S. Niesiołowski specjalizuje się jako profesor nauk biologicznych].

S. Niesiołowski: „Ja się nie obrażam”.

J. Hartman: „To pan mnie obraża tutaj, a nie ja pana. Żeby nie było wątpliwości".

S. Niesiołowski: „Zostawmy to”.

J. Hartman: „Pan mnie lży w sposób tak komiczny i groteskowy, że ja się nie obrażam".

S. Niesiołowski: „Pan jest tak wielkim człowiekiem, że rozumiem, że pana można lżyć tylko w sposób komiczny".

25 Kłótnia o Kaczyńskiego. Staniszkis wyszła ze studia TVN24, http://wiadomosci.gazeta.pl/ Wiadomosci/1,80708,8009863,Klotnia_o_Kaczynskiego__Staniszkis_wyszla_ze_studia.html, odczyt z 30.08.2011.

26 Spór o uchwatę. „Ruch Palikota po prostu nienawidzi Kościoła”, www.tvn24.pl/kropka-nad-i, 3,m/spor-o-uchwale-ruch-palikota-po-prostu-nienawidzi-kosciola,420944.html, odczyt z 25.04.2014. 
J. Hartman: „Właśnie tak pan to robi”.

S. Niesiołowski: „Oczywiście, pan jest tak doskonały”.

W innym miejscu Stefan Niesiołowski zarzuca Janowi Hartmanowi, że sięga po „stalinowską retorykę”. W odpowiedzi słyszy zarzut, że „mówi językiem obraźliwym i oszczerczym”. Istotne w ocenie tych dialogów wydaje się to, iż miały miejsce w programie poświęconym dyskusji na temat projektu sejmowej uchwały upamiętniającej kanonizację Jana Pawła II. Szczególnie więc razi w tym przypadku zderzenie fragmentów rozmowy na temat ideałów i papieskiego nauczania z tymi elementami dyskusji, w których padają argumenty nie mające wiele wspólnego z merytoryczną debatą.

Naiwne byłoby oczywiście twierdzenie, że przywołane powyżej przykłady odsłaniają zupełnie nowe zjawisko w dyskursie naukowym. Mediatyzacja przecież nie zawsze kieruje nasz wzrok w stronę nieodkrytych dotąd procesów. Pomaga nam też widzieć „stare” pytania stawiane w komunikologii i socjologii mediów w nowym świetle i wyznacza nowe frapujące drogi poszukiwania na nie odpowiedzi ${ }^{27}$. Mamy więc świadomość, że pytanie - jak dyskutować? - jest stawiane od dawna. Można by tu oczywiście przywołać przykład sprzed wieków, ale ograniczmy się w tym miejscu do refleksji sprzed kilku dekad. Brytyjski fizyk John Ziman przypominał, że w nauce obowiązują zasady, które „bardzo wyraźnie potępiają stosowanie argumentum ad hominem, jadowitych ataków osobistych i publicznego obrzucania błotem" ${ }^{28}$. Nie widział jednak nic dziwnego w tym, że przedstawiciele świata nauki ze sobą dyskutują i że czasem są to wręcz żywe polemiki. Ale jak zauważał w swoim eseju zatytułowanym "Społeczeństwo nauki”, takie właśnie jest zadanie naukowca - „umieć skutecznie bronić swojej sprawy, a zarazem z godnością przyjmować porażkę i nie traktować jej jako osobistej urazy"29. Spór pomiędzy naukowcami, nawet ten bardzo wyrazisty, Ziman widział jako swoisty rodzaj współpracy. Przyrównywał go do sądowej potyczki pomiędzy adwokatem a prokuratorem, „czyli urzędnikami prawa dążącymi w pierwszym rzędzie do wymierzenia sprawiedliwości, co nie przeszkadza, że po zrzuceniu togi i peruki udają się w najlepszej zgodzie na wspólny posiłek" ${ }^{30}$. Taki scenariusz uznać należy za stan pożądany czy idealny, ale pamiętać też trzeba, że nie zawsze daje się do niego doprowadzić. John Ziman miał tego pełną świadomość. Pisał bo-

27 K. Lundby, Introduction: „Mediatization” as Key, [w:] idem, Mediatization: Concept, Changes, Consequences, New York 2009, s. 8.

28 J. Ziman, Społeczeństwo nauki, Warszawa 1972, s. 210.

29 Ibidem, s. 208.

30 Ibidem. 
wiem, że „wśród zdolnych naukowców jest wielu żywiołowych, złośliwych ludzi, zdolnych w otwartej dyspucie zranić swego przeciwnika głębiej, niżby zamierzali. Ci zaś, których natura obdarzyła szczególną drażliwością i skłonnością do zazdrości, łatwo się obrażają i wpadają w gniew, jeśli tylko odczują coś, co ma rzekomo uchybiać ich zawodowej sławie"31.

\section{Ucieczka czy podjęcie wyzwania?}

Co może więc zrobić politolog, obserwując taki a nie inny stan medialnej - zmediatyzowanej - debaty i zdając sobie sprawę ze związanych z nią zagrożeń? Reakcje i postawy mogą być oczywiście różne. Jedną z możliwych odpowiedzi jest niechętny stosunek do mediów, czy konkretniej - niechęć wobec telewizyjnych lub radiowych dyskusji. Zdarza się więc - i nie jest to zjawisko marginalne - że przedstawiciele świata nauki odmawiają udziału w debatach prowadzonych przed radiowymi mikrofonami i telewizyjnymi kamerami. Taką postawę tłumaczą chęcią zaprotestowania przeciwko spłycaniu języka, nadmiernej skrótowości lub banalizacji przekazu w mediach.

Badacze włączający się w medialny dyskurs nierzadko zwracają uwagę na funkcjonującą w tym obszarze antynomię - język tabloidowy połączony z emocjonalizacją dyskursu kontra język przeteoretyzowany. Warto się zastanowić na tym czy to jedyne możliwe rozwiązania i czy nie warto upominać się o swoistą „trzecią drogę", odwołującą się do merytorycznego, ale klarownego przekazu i komunikatywnego języka, odnoszącego się do specjalistycznych pojęć tylko wtedy, kiedy jest to absolutnie niezbędne i gdy pojęcia te nie są pozostawiane bez komentarza i wyjaśnienia. Takie podejście wymaga oczywiście pracy obu stron - zarówno gospodarzy, jak i gości programów publicystycznych z udziałem przedstawicieli świata nauki.

Gdy ludzie nauki rezygnują z udziału w medialnych debatach, niewątpliwie unikają związanego z takimi dyskusjami ryzyka. Pytanie tylko, czy to rzeczywiste rozwiązanie problemu? Należy raczej uznać, że unikanie debat przed kamerami i mikrofonami jest niczym innym jak drogą na skróty, albo - używając dosadniejszego określenia - rejteradą. Owszem - zgodzić się należy, że politolog nie musi występować w mediach, żeby być, istnieć jako naukowiec. Politolog nie jest politykiem - nie musi więc swoją medialną aktywnością udowadniać światu, że ma wartość. Zatem czy politologom jest w ogóle potrzebna aktywność medialna?

31 Ibidem. 
Zasadniczym argumentem przemawiającym za taką aktywnością jest przywołany wcześniej aspekt misji, która spaja środowisko naukowe - misji objaśniania rzeczywistości. Media mogą być szczególnie pomocne w realizacji tego zadania, skoro stanowią platformę, która umożliwia i ułatwia komunikację między grupami społecznymi oraz rozmaitymi podmiotami funkcjonującymi w zasięgu tych mediów.

\section{Politolog prodemokratyczny}

Jeśli zgodzimy się, że obecność przedstawicieli świata nauk o polityce jest ważnym elementem budowania świadomości społecznej i wiedzy na temat procesów zachodzących w polityce, warto zastanowić się nad tym, jak tę obecność czynić skuteczniejszą i bardziej merytoryczną. Kilka wskazówek możemy znaleźć w Dekalogu Prodemokratycznego Politologa, stworzonym i zaprezentowanym przez prof. Mariusza Gulczyńskiego ${ }^{32}$. W zestawie tym znalazły się następujące konstatacje:

1. Jestem politologiem - nie politykiem.

2. Jestem politologiem stronniczym socjocentrycznie - opozycyjnym wobec kratocentrycznych interpretacji polityki.

3. Prodemokratyczność pojmuję jako opowiadanie się za wyrównywaniem politycznych uprawnień i obowiązków oraz socjalnych szans życiowych całych i wszystkich narodów.

4. Zakładam, że prodemokratyczna stronniczość wymaga preferowania kompromisowości a nie konfliktowości w polityce.

5. Opowiadam się za służebnością przez pomoc w rozumieniu procesów politycznych - przeciwko służalczości zarówno wobec rządzących, jak i populistycznych zapotrzebowań.

6. Wyrokowanie na podstawie czynów a nie słów - to podstawowa reguła mojego politologicznego warsztatu.

7. Jestem historiozofem - wiedzę o prawidłowościach procesów politycznych dedukuję z powtarzalności pokrewnych zjawisk w dziejach ludzkości.

8. Twierdzę, iż prodemokratyczny politolog winien badać nie tylko zdrowe, lecz i chore aspekty polityki oraz sugerować adekwatne remedia profilaktyki i kurowania.

32 Dekalog ten został przedstawiony w ramach ogólnopolskiej konferencji naukowej Aspekty metodologiczne oraz teoretyczne w subdyscyplinach politologii zorganizowanej przez Instytut Politologii Uniwersytetu Zielonogórskiego w maju 2011 roku w Zielonej Górze. 
9. Jestem osobiście odpowiedzialny za to, co upubliczniam jako wiedzę o polityce z własnych badań i konstatacji innych naukowców.

10. Upubliczniam to, co wiem o polityce - zgodnie z demokratycznymi zasadami wolności słowa oraz obowiązku transparentności polityki, a zatem i politologii.

Powyższy zestaw nie jest oczywiście zbiorem bezwzględnych nakazów, a jedynie propozycją, oddolną inicjatywą stworzenia reguł i zasad, którymi w swojej pracy powinni lub też mogliby kierować się badacze zajmujący się obserwowaniem zjawisk, procesów, aktów i systemów politycznych. Z całą pewnością przedstawionego „dekalogu” nie trzeba bezkrytycznie przyjmować i wdrażać w życie. Ale można go potraktować jako zaproszenie do dyskusji nad odpowiedzialnością politologa w warunkach mediatyzującej się rzeczywistości. Im więcej takich zaproszeń i pozytywnych na nie odpowiedzi, tym większe korzyści mogą płynąć nie tylko dla środowiska naukowego, ale i jego otoczenia. Jeśli bowiem, zgodzimy się z Mariuszem Gulczyńskim, że zadaniem prodemokratycznego politologa jest wskazywanie dróg uzdrawiania polityki - nie możemy nie zadać pytania, czy „lekarze” nie powinni rozpoczynać kuracji od siebie, to znaczy od promowania pozytywnych wzorców w swoim środowisku? 